\title{
How Much Do Rice Farmers Earn from Their Crops? Evidence from a Rice-Exporting Country
}

\author{
Tran Quoc Nhan (Corresponding author) \\ College of Rural Development, Can Tho University \\ 61 National Road, Phung Hiep District, Hau Giang province, Vietnam \\ E-mail: tqnhan@ctu.edu.vn \\ Le Thi Van Ly \\ College of Rural Development, Can Tho University \\ 61 National Road, Phung Hiep District, Hau Giang province, Vietnam \\ E-mail: lyb1605951@ @student.ctu.edu.vn \\ Le Van Tan \\ College of Rural Development, Can Tho University \\ 61 National Road, Phung Hiep District, Hau Giang province, Vietnam \\ E-mail: tanb1606078@student.ctu.edu.vn
}

Received: Nov. 29, 2019

Accepted: Feb. 4, 2020

Published: Feb. 5, 2020

doi:10.5296/jas.v8i1.16402

URL: https://doi.org/10.5296/jas.v8i1.16402

\begin{abstract}
This study aims to investigate the earning capability of rice-farming households in Vietnam's Mekong Delta. The Delta is recognized as the largest rice-producing region in Vietnam that is known as the world's third rice exporter. We used data collected from a farm-household survey with 110 rice farmers and applied descriptive statistics and correlation model for data analysis. We found that although the production scale of rice farmers is relatively small, their rice cultivation is profitable. The findings illustrated that the rice-farming household's income
\end{abstract}


was significantly associated with rice income and rice land size. This suggests that the rice households' income is likely to rely on their farm size. Evidence from the study showed that rice households, particularly small-scale farms earn low income and they are likely to remain poor and in a state of poverty. The implication of the study may be that the Vietnamese government should amend the policy on rice land use and pay more considerable attention to small-farm households.

Keywords: rice household, earning, profitability, Mekong Delta

\section{Introduction}

The developmental performance of Vietnam in the last three decades is seen as the most spectacular among developing countries (OECD, 2013). The rapid growth of the agricultural sector and the rice sub-sector, in particular, has been serving as the foundation of Vietnam's success story. The rice industry in the Mekong Delta, the country's rice "bowl", has transformed Vietnam from being a rice deficit to being a rice surplus economy (Demont, 2017). The Delta supplies annually over $56 \%$ of the total paddy production and $95 \%$ of the total volume of export rice in Vietnam (GSO, 2016) while occupying only $12 \%$ of the total national land area.

The fact is that since the Doi Moi or renovation policy initiated by the Communist Party Congress in 1986, the Vietnamese economy had shifted from a centrally planned economy to a market-oriented economy. The major goals of this renovation policy are to promote the liberalization of the domestic market allowing free trade and the free market prices, to reform state-owned enterprises, and to acknowledge private enterprises and companies with foreign investment. One of the most crucial features of this policy is the legalization of private sector. Indeed, in the agricultural sector under the framework of this policy Politburo Resolution No. 10 was promulgated in 1988, which placed great emphasis on granting land use rights to individual households, and allowing private sector participating in agricultural markets (liberalization of output market and input supply).

After implementing Resolution No. 10, the Vietnamese agricultural sector has generated a huge output surplus, particularly, the rice surplus, which allowed Vietnam (which prior to 1989 was a net importer of rice due to consequence of war and failure of policy making) to be able to participate in the international rice markets with the first rice export volume of 1.37 million tons equivalent to the value of approximately 310 million USD in 1989. In the recent years, Vietnam has been known as the third largest rice exporters in the world market, accounting for approximately $18 \%$ of the international rice market share but it's export price for rice is fairly low compared to that of other rice exporting countries (FAO, 2016).

Rice exports in Vietnam play a crucial role as an instrument to generate foreign exchange revenues which are used to import necessary commodities for the domestic economy as well as finance for the development of manufacturing and service sectors (Anh et al., 2013). In fact, Vietnam gained more than 30 billion USD from rice export with approximately 70 million tons of rice during the 2005-2016 period. The export of the rice product is considered one of the most important components of the Vietnamese agriculture economy, gaining an average of more than 2 billion USD annually. However, the most important role of rice 
production is to ensure food security and political stability of the nation because rice is the main food for more than 94 million Vietnamese people.

Realizing the importance of the rice sector in the Mekong Delta to national food security and exports following the world's food crisis in 2008, the government of Vietnam in 2009 promulgated Resolution No. 63/NQ-CP on national food security. As a result, it has been decided that about 1.75 million ha of rice land be set aside for rice production, equivalent to about 3.8 million ha of rice planted area maintained in the Mekong Delta (farmers can practice 2-3 rice crops per year). To achieve this mission, the government in 2012 issued Decree No.42/2012/ND-CP on rice land use and management, which was amended by Decree No.35/2015/ND-CP (2015). The before mentioned policies and regulations therefore meant that farmers whose lands were already registered as rice lands were now prohibited from switching the rice-land use to the production of other crops and to other functions (that may have the potential to generate more income for the farmer household), thus maintaining the rice land quota as stipulated in Resolution No. 63/NQ-CP. This seemingly forced rice farmers to retain their rice land area and focus entirely on rice cultivation. Therefore, it is crucial to measure the earning capacity and savings for rice-farming households in this region. In other words, the question that should be answered is, rice farmers in the Mekong Delta wealthy under the Vietnamese government's policy on rice land use?

\section{Literature Review}

As it was mentioned before, the Mekong Delta is known as a "rice bowl" of Vietnam. Thus, studies on rice in this region are often conducted. In fact, we found many previous studies on rice issues in Vietnam and more specifically in the Mekong Delta, which focused on technical efficiency of rice production (e.g., Hien et al., 2003; Chi \& Yamada, 2005; Huy, 2009; Khai \& Yabe, 2011; Duy, 2015; Dang, 2017b) and profit efficiency of rice farming (e.g., Hoang \& Yabe, 2012; Trong \& Napasintuwong, 2015; Dang, 2017a). Other studies are paid considerable attention to rice marketing (e.g., Hai, 2004; Hai, 2005; Luts, et al., 2006; Baulch et al., 2008; Loc \& Son, 2011).

However, it was difficult to find any study that focuses on income capacity and the profitability of paddy farming in the Mekong Delta, Vietnam. We found several earlier empirical studies regarding profitability of rice farming. Dung et al. (2017) investigated the financial capacity of household such as net income, long-standing debt and savings of paddy farming household in four agro-ecological zones (flood, alluvial, acid soil and saline) in the Mekong Delta and found that farm size, land use circle and non-farm activities had a positive correlation with household saving in all of the agro-ecological zones. In a case study of 196 rice farmers in Tra Vinh province of the Mekong Delta, Dang (2017a) revealed that the profit efficiency of rice production was an average of $75.61 \%$. The results also showed that education attainment, household labor, farm size, technical training attendance, and farmer's association membership had a positive effect on profit efficiency of rice farmers. By using the stochastic frontier analysis method with a stochastic trans-log normalized profit frontier function, Trong and Napasintuwong (2015) illustrated that the average profit efficiency for hybrid rice farmers in Central Vietnam was relatively low, on average 63\%. They also found 


\section{Macrothink}

that age, education, irrigation, share of rice income, share of hybrid rice area, training attendance, experience, and topography were major factors affecting profit inefficiency. Another study by Hoang and Yabe (2012) found that the profit efficiency of rice production was approximately $75 \%$, and environmental factors (plant disease, soil fertility, irrigation apply and water pollution) caused a large reduction in profit for rice growers. Generally, these authors did not analyze earning capacity for rice-farming households.

Therefore, in an effort to document some evidences on income capacity of rice-farming households particularly small-scale farmers, this study aims to sheds light on the earning capability of small-scale rice growers in Vietnam's Mekong Delta using data collected from 110 rice farmers in Hau Giang province which is known as the heart of the Mekong Delta. The present study attempts to fill the gap in the empirical literature which contains little evidence on the income capacity of rice-farming households in Vietnam's Mekong Delta.

\section{Methodology}

\subsection{Data Collection}

The data collection was conducted through four steps in August 2019. First, we identified the study areas by utilizing existing data and papers and advice from local officials. Second, we conducted a pre-test of structured questionnaire to adjust questions in the questionnaire. Third, we conducted face-to-face interviews with 110 rice-farmers. The respondents were randomly selected from the list of rice-farming households provided by the commune people's committee. Last, the field survey was officially carried out in Chau Thanh A and Phung Hiep districts of Hau Giang province. This province was chosen because it is a typical region for rice production in the Mekong Delta.

A structured questionnaire consisting of various questions was used to gather detailed household-level data such as demographic characteristics, participation in farmer-based organizations, landholdings, farm assets, income sources, rice production (family and hired labors, inputs use, production cost, output prices, output volume).

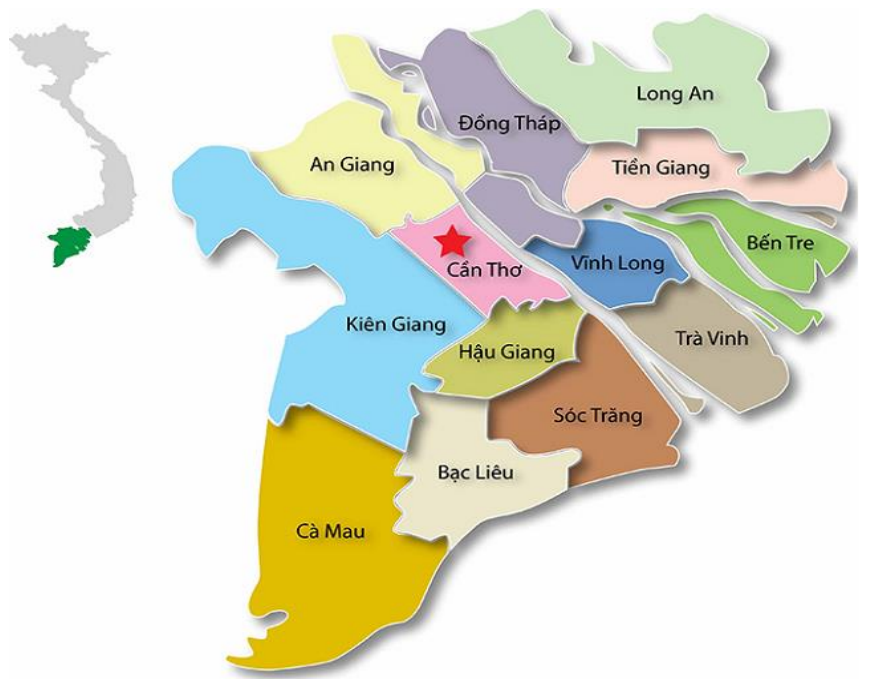

Figure 1. Location of study site 


\subsection{Analytical Techniques}

We mainly used descriptive statistics to analyze the collected data. We employed a simple cost-benefit analysis to measure the profitability of rice production, focusing on average variable cost, average return obtained for one hectare and average rate of return. The earning capacity of rice households was mainly estimated based on per capita income within rice-farming households.

\section{Results and Discussion}

\subsection{Characteristics of Rice-Farming Households}

Table 1 shows the definition of variables and mean values of socio-economic characteristics of rice-farming households in the study areas. In terms of human capital, the results showed that the household head's age is approximately 52 years old but they have long experience in rice farming, around 24 years of doing rice cultivation. This implies that they have been involved in the cultivation of this crop for about half of their lives. The educational level of the heads of surveyed households is moderate, approximately 6.5 years of schooling. The household size is likely medium, approximately 5 members. The investigation also indicated that the head of the households is mainly the man who is also responsible for farming activities.

With respect to production scale, the rice land size of households is medium, around 1.48 ha accounting for approximately $81.32 \%$ of total land size, as compared to the average farm size in the Mekong Delta of 1.4 ha. According to GSO (2012) a large number of rice farmers in the Mekong delta are small-size farmers, approximately $65 \%$ and $20 \%$ of them owning less than 1 ha of rice land and ranging between 1 and 2 ha, respectively; yet only $15 \%$ of rice households hold more than 2 ha of rice land. Regarding cropping pattern, almost all farmers in the study areas practice three rice crops a year because these regions place emphasis on rice cultivation.

In terms of social participation, participation in farmer organizations (e.g., an agricultural cooperative, cooperative group, or extension club) may play a crucial role in enhancing farmers' social capital and providing more opportunities for farmers to access extension services and expand their public relations. The share of interviewed farmers participating in such organizations is relatively small, only $15 \%$ of respondents participating in one of three such organizations.

With regard to household's assets, in terms of means of telecommunications, all interviewed farmers have cellphone and television that are very helpful to them. Indeed, farmers usually get update to date information on farming technique and pricing on television program and also use cellphone to make contact with rice purchasers and other farmers to ask about the pricing of rice. With respect to means of transportation, motorbike has been widely used in the rural areas of the Mekong region because the rural road infrastructure has been developed but it is difficult for car to access this road. Respondents reported that all of them have at least one motorbike. However, only $75 \%$ of surveyed households own a small boat with a small loading capacity which is mainly used for transporting farming inputs including 
fertilizers, seed and pesticides. This is primarily due to the underdeveloped road system that makes farms inaccessible by truck. However, evidence from the investigation indicated that almost all surveyed households have a sprayer but do not own other farm assets such as tractor, combine harvester and storage for paddy.

Table 1. Socio-economic characteristics of rice farm households

\begin{tabular}{|c|c|c|c|c|}
\hline Variables & Min & Max & Mean & S.D \\
\hline Age of household head (year) & 28 & 83 & 51.76 & 10.471 \\
\hline Rice-farming experience of head (year) & 3 & 55 & 23.95 & 10.802 \\
\hline Education of head (years of schooling) & 1 & 12 & 6.50 & 2.941 \\
\hline Family size (person) & 2 & 11 & 4.81 & 1.594 \\
\hline Total land size (ha) & 0.2 & 20.8 & 1.82 & 2.267 \\
\hline Rice land size (ha) & 0.2 & 10 & 1.48 & 1.279 \\
\hline $\begin{array}{l}\text { Cropping pattern (number of crops per } \\
\text { year) }\end{array}$ & 2 & 3 & 2.92 & 0.275 \\
\hline $\begin{array}{l}\text { Membership in farmer's organization } \\
\text { (dummy) }\end{array}$ & 0 & 1 & 0.15 & 0.354 \\
\hline Sprayer ownership (dummy) & 0 & 1 & 0.91 & 0.289 \\
\hline Boat ownership (dummy) & 0 & 1 & 0.75 & 0.432 \\
\hline
\end{tabular}

Source: Own estimates

\subsection{Rice-Farming Profitability}

The investigation indicated, that almost all sampled households applied triple rice crops per year, which suggests that rice farming in the study area is extremely intensive. Generally, rice cropping seasons in the Mekong Delta can be classified into three crops. First, the winter-spring crop which is often cultivated in November-December and harvested in February-March. Second, the summer-autumn crop, normally planted in April-May and harvested in July-August. Third, the autumn-winter crop, which is started immediately after the summer-autumn crop and harvested in October-November. This is considered the short season crop. The winter-spring rice crop was chosen to measure the profitability of rice cultivation in this study because this is the main crop in which most farmers cultivate it.

Table 2 reports profitability analysis of rice production for rice-farming households in the study area. Variable costs consisting of costs of seed, fertilizer, pesticide; labor, machinery, and fuel were used to calculate production cost and income from rice production. According 
to farmers' perspective, seed plays a key factor in rice production because it can potentially improve the productivity and quality of rice. Most farmers bought and applied certified seed; few of them used their paddy from previous season as seed. Farmers across the sample used several kinds of varieties but a household usually applied only one variety. The investigation showed that cost of seed was approximately $13.44 \%$ of total variable cost.

Before transplanting or broadcasting paddy, land preparation is considered a crucial factor that may affect rice productivity. Land preparation can be described as the use tractor to plow and till a soil to make it porous, improve water holding capacity and help plant grow faster. Most farmers used ploughing service (hiring labor and tractor) for land preparation. Cost of land preparation accounted for $7.34 \%$ of total cost.

With respect to application of fertilizer and pesticide, farmers across the sample reported that they mostly use inorganic fertilizers such urea (nitrogen), DAP (phosphorus and nitrogen), NPK (nitrogen, phosphorus and potassium) and Kali (potassium). These are applied about 4 times per crop. Fertilizer cost accounted for $22.43 \%$ of total cost, which is considered as the second largest share of cost structure. In terms of agro-chemical use, Table 2 presents that the cost of agro-chemicals (pesticide, herbicide, fungicide) was the highest proportion, approximately $30 \%$ of total cost. The farmers used several kinds of agrochemicals such as pesticide, herbicide, fungicide and foliage fertilizer because of high risk of diseases and pests on paddy such as rice blast and brown plant-hopper which may be caused by intensive rice farming. Farmers often apply agro-chemicals 6-8 times per crop. This implies that the increase in agro-chemicals use was likely to reduce the profits and it may also influence the quality of rice product (product safety) and environmental problems.

Irrigation cost appeared as the lowest cost, approximately $3.45 \%$ of total cost structure. The paddy fields in the study areas are often protected by dike systems to prevent seasonal flooding in which farmers can practice three rice crops per year. Thus, farmers often pump water from canal into the field in the dry season and pump water out the field in the wet season. The average cost of harvesting constituted $16.7 \%$ of the total cost structure. Most farmers hired combine-harvester servicing providers for cutting and threshing their paddy. This machine is widely used in the Mekong Delta mainly due to its low cost per unit as compared to manual harvesting.

With regard to labor cost, farmers usually hire extra labors for planting paddy (broadcasting and transplanting), applying pesticide and fertilizer, removing weed and differential varieties from previous seasons to make paddy product uniform. In this category, we calculated all labors cost including hired and family labor. This cost accounted for approximately $9.5 \%$ of the cost structure

The gross margin or average return is defined as the difference between revenue and variable costs. The result in Table 2 showed that the gross margin obtained per ha was 18 million VND. The return on investment value obtained was approximately 1.13 , implying that farmers may earn a return of 1.13 million VND for every 1.00 million VND invested in rice cultivation, which suggests that rice production in the research area is relatively profitable. 
Table 2. Analysis of cost and return in paddy production per hectare

\begin{tabular}{lccc}
\hline Variables & Mean Value & S.D & $(\%)$ \\
\hline Major variable costs (VND) & $16,511,894$ & $2,062,152$ & 100.00 \\
Seed cost & $2,218,408$ & 514,602 & 13.44 \\
Land preparation cost & $1,211,793$ & 273,463 & 7.34 \\
Fertilizer cost & $3,703,642$ & $1,118,449$ & 22.43 \\
Pesticide cost & $4,942,898$ & 773,620 & 29.94 \\
Irrigation cost (water pumping) & 569,453 & 330,320 & 3.45 \\
Labor cost (hired and family) & $1,573,217$ & 239,135 & 9.52 \\
Harvesting cost & $2,760,573$ & 349,944 & 16.72 \\
Yield (kg/ha) & 7,246 & 8,582 & - \\
Revenue (VND) & $18,335,477$ & $5,648,584$ & - \\
Gross margin (VND/kg) & 1.13 & 0.378 & - \\
Return on investment & & & \\
\hline
\end{tabular}

Source: Own estimates

\subsection{Earning Capacity of Rice-Farming Households}

The major source of income for surveyed households mainly comes from rice production, which generates approximately $73 \%$ of their total income. This implies that good performance of rice production is an important strategy to create livelihood for rice-farming households in the Mekong Delta.

We measured the earning capability of rice households in the study area by monthly average per capita income. The results in Table 3 showed that monthly average income per person within the surveyed households was approximately 2 million VND equivalent to 86.62 USD (1 USD is taken here as 23,000 VND, based on foreign exchange rate of Vietnam state bank at the time of the survey). This amount is less than $43 \%$ and $48 \%$ of monthly average income per person in Hau Giang province (3.548 million VND) and Vietnam (3.876 million), respectively (GSO, 2018). These findings suggest that rice-farming households located in rural areas in Vietnam have low income. This income is relatively close to the poverty line for people living in Vietnam's rural area. According to the regulation of the Vietnamese government, a person who lives in rural area is considered poor if they receive a monthly 
average income of less than 1 million VND (44 USD). It may be concluded that it is hard for rice-farming households in the Mekong Delta to live on the income derived from their rice production, even if their rice cultivation is profitable.

Table 3. Rice-farming household's income

\begin{tabular}{lccr}
\hline Variables & $\begin{array}{c}\text { Mean value } \\
\text { (VND) }\end{array}$ & S.D & $\%$ \\
\hline Rice income (all crops) & $81,236,631$ & $80,171,389$ & 73.97 \\
Income from other farming activities & $7,463,636$ & $19,184,606$ & 7.38 \\
Income from off-farm activities & $14,390,909$ & $27,351,982$ & 14.39 \\
Income from remittance & $5,590,909$ & $3,471,151$ & 4.26 \\
Total income & $108,682,086$ & $86,715,147$ & 100 \\
Monthly average income per capita & $1,992,171$ & $1,482,081$ & \\
\hline
\end{tabular}

Source: Own estimates

As discussed, rice income is the main source of earning for rice households in the surveyed areas. In fact, the findings in Table 4 showed that the rice household's income has strong positive association with rice income and rice land area, which suggest that the rice household's income is likely to rely on performance of rice cultivation and rice land size.

Table 4. Correlation between households' income and rice income and rice land area

\begin{tabular}{lrrrr}
\hline & & Total income & Rice income & Rice land area \\
\hline Total income & Pearson Correlation & 1 & & \\
& Sig (2-tailed) & & \\
Rice Income & Pearson Correlation & $0.863^{* *}$ & 1 & \\
& Sig (2-tailed) & 0.000 & & 1 \\
Rice land & Pearson Correlation & $0.777^{* *}$ & & \\
area & Sig (2-tailed) & 0.000 & & \\
\hline
\end{tabular}

Source: Own estimates

\section{Conclusion}

Farmers in the study area have long experience in the rice farming and educational level of household head is moderate. The investigation showed that a majority of rice-farming households do not own agricultural assets such as tractor, harvester, dryer and storage facility. This finding may reflect the fact that rice-farming households may lack capital to purchase 
these assets.

Rice production is considered an important component to generate a majority of rice-farming household's income. The findings of the study may conclude that rice cultivation across the sample is profitable. However, rice farmers are unlikely to maintain and operate their rice farms for their livelihood on a long-term basis since their earning from rice farming is fairly low, resulting from their small farm size.

The evidence of the study showed that rice households, particularly small-scale households, have relatively low income when compared to per capita income of Vietnamese people. Although Vietnam is well-known as one of top three countries for rice export, a majority of rice-farming households have per capita income as that of the poor in Vietnam. The Vietnamese government should reconsider the policy on rice land use, and evaluate the impact of this policy on rice farmers' livelihood.

\section{References}

Anh, D. T., Reardon, T., Chen, K., Tinh, T. V., Nguyen, M. S. V., Vang, N. N., ... Khoi, L. N. D. (2013). Rice value chain study in the Mekong delta, Vietnam. Asian Development, Hanoi, Vietnam.

Baulch, B., Hansen, H., Trung, L. D., \& Tam, T. N. M. (2008). The spatial integration of paddy markets in Vietnam, Journal of Agricultural Economics, 59(2), 271-295. https://doi.org/10.1111/j.1477-9552.2007.00148.x

Chi, T. T. N., \& Yamada, R. (2005). Assessing the technical efficiency of input in rice production in Thai Lai commune, Co Do district, Can Tho city, Omonice, 13, 116-120.

Dang, N. H. (2017a). Profitability and profit efficiency of rice farming in Tra Vinh province, Vietnam, Review of Integrative and Economics Research, 6(1), 191-201.

Dang, N. H. (2017b). Technical efficiency and its determinants: a case of rice production in Tinh Bien District, An Giang Province, Vietnam, IJETM, 4(2), 19-27.

Demont, M., \& Rutsaert, P. (2017). Restructuring the Vietnamese rice sector: Towards increasing sustainability. Sustainability, 9(325), 1-15. https://doi.org/10.3390/su9020325

Dung, L. C., Ha, V. V., Tuan, V. V., Nhan, D. K., Ward, J., \& Brown, P. (2017). Financial Capacity of Rice-based Farming Households in the Mekong Delta, Vietnam. Asian Journal of Agriculture and Development, 14(1), 73-87.

Duy, V. Q. (2015). Access to credit and rice production efficiency of rural households in the Mekong delta, Sociology and Anthropology, 3(9), 425-433.

https://doi.org/10.13189/sa.2015.030901

FAO (2016). Rice market monitor. Food and Agriculture Organization of the United Nations, Rome, Italy

GSO (General Statistic Office) (2016). Statistical Yearbook of Vietnam. Statistical Publishing House, Hanoi, Vietnam 


\section{Al Macrothink}

Journal of Agricultural Studies

ISSN 2166-0379

2020, Vol. 8, No. 1

GSO (General Statistic Office) (2018). Statistical Yearbook of Vietnam. Statistical Publishing House, Hanoi, Vietnam

GSO (General Statistics Office) (2012). Results of the 2011 rural, agriculture and fishery census. Statistical Publishing House, Hanoi, Vietnam

Hai, L. T. D. (2004). Rice market integration in Mekong delta the successful liberalization of domestic food market in Vietnam, Can Tho Uni. J. of Science, 1, 186-197 (in Vietnamese with English summary)

Hai, L. T. D. (2005). The Analysis of Rice Marketing Costs and Rice Distribution System in The Mekong River Delta, Can Tho Uni. J. of Science, 3, 138-147 (in Vietnamese with English summary)

Hien, N. T. M., Kawaguchi, T., \& Suzuki, N. (2003). A study on technical efficiency of rice production in the Mekong delta, Vietnam by Stochastic Frontier Analysis, J.Fac.Agr., Kyushu Univ., 48(1-2), 325-357.

Hoang, L.V., \& Yabe, M. (2012). Impact of environmental factors on profit efficiency of rice production: a study in Vietnam's Red river delta, World Academy of Science, Engineering and Technology, 66, 97-104.

Huy, H. T. (2009). Technical Efficiency of Rice-Producing Households in the Mekong Delta of Vietnam, Asian Journal of Agriculture and Development, 6(2), 35-50.

Khai, H. V., \& Yabe, M. (2011). Technical efficiency analysis of rice production in Vietnam. Journal of ISSAAS, 17(1), 135-146.

Loc, N. T. T., \& Son, N. P. (2011). Value chain analysis of rice product in the Mekong Delta, Can Tho Uni. J. of Science, 19(a), 96-108 (in Vietnamese with English summary)

Luts, C., Praagman, C., \& Hai, L. T. D. (2006). Rice market integration in Mekong river delta: the transition to market rules in the domestic food market in Vietnam, Economics of Transition, 14(3), 517-546. https://doi.org/10.1111/j.1468-0351.2006.00260.x

OECD (2013). Managing aid for trade and development results in Vietnam. In: Aid for trade and development results: a management framework. OECD Publishing: Paris, France. https://doi.org/10.1787/9789264112537-en

Trong, P. H., \& Napasintuwong, O. (2015). Profit inefficiency among hybrid rice farmers in Central Vietnam, Agriculture and Agricultural Science Procedia, 5, 89-95. https://doi.org/10.1016/j.aaspro.2015.08.013

\section{Copyright Disclaimer}

Copyright for this article is retained by the author(s), with first publication rights granted to the journal.

This is an open-access article distributed under the terms and conditions of the Creative Commons Attribution license (http://creativecommons.org/licenses/by/4.0/). 